\title{
RELATIONSHIPS OF MIRZA FATALI AKHUNDZADA WITH HIS CONTEMPORARIES IN THE FIELD OF STRUGGLE FOR NEW ALPHABET
}

Musayev Shahbaz Shami ${ }^{1}$

Abstract: The article investigates the new idea of alphabet of M.F.Akhundzada and the socialscientific relationships with his contemporaries in the field of realizing this idea. It is noted that the idea of new alphabet constitutes the basis of the concept of enlightenment. According to the rich scientific and epistolary heritage of writer-thinker, he put forward the issue of the necessity of alphapet reform giving ground that it causes to the massive illiteracy and non-compliance with Arabic alphabet used in Azerbaijan to the phonetic nature of Azerbaijan language as the result of social-historical processes and making special difficulties in teaching process. However M.F.Akhundzada doesn't consider his mission to be completed with putting forward an idea, he made a new alphabet and sent it to the official counties of the
Ottoman Empire and Iran, as well as the scientific centers of the important five countries of Europe for discussing it. The article has investigated the visit of M.F.Akhundzada to İstanbul and its results, as well as the correspondences with the official counties of Iran and consultations with his contemporariesfor discussing new alphabet project. The article as involved to the study of letters he sent to his contemporaries, his relevant writings kept in the archive of M.A.Akhundzada, and appreciated the idea and considerations of other researchers about the problem. The Article clarifies the reasons of not realizing the idea of new alphabet of M.F.Akhundzada, and showed historical-culturological importance of this idea. It is noted that new alphabet idea collected supporters during little time, the issue of changing Arabic

\footnotetext{
${ }^{1}$ Associate Professor, Doctor of Philosophy Inphilology, Leadingscientist of Institute of Literature named after Nizami Ganjavi of Azerbaijan National Academy of Sciences, Azerbaijan. E-mail: shindi61 @ mail.ru. ORCID: https://orcid.org/0000-0002-7238-5216
} 
alphabet became social requirement in society and after Azerbaijan regained its state independence, the country started to Latin graphics alphabet.

Kewwords: Mirza Fatali Akhundzada, enlightenment concept, modernization of society, new alphabet idea.

\section{Introduction}

Mirza Fatali Akhundzada (1812-1878) is one of the outstanding representatives of history of literaryartistic, cultural, scientific-philosophical thought of Azerbaijan. He founded national dramaturgy with comedies he wrote in 1850-1855 years, and realistic artistic prose with novella "The Deceived Stars" written in 1857 and thus he gained a great reputation as a founder of modern literature in his country and also in the whole East. He was also known as the first literary theorist and professional critic for his literarytheorotical views in Azerbaijan.

M.F.Akhundzada understands well as an enlightened realist writer and he was writing to his contemporaries that it's possible to heal the sick society drowning in ignorance and the religious
808

fanaticism only by a new type literature related to the real life. M.F.Akhundzada shows that in the period of the world nations seeking progress and in new socio-political condition, traditional Eastern literature genres and especially ghazal and ode not related to real life, already have not working for people and he preferred essentially social literature that leads to national progress, serving for the progress of society, arose from the demands of the time. Deeply acquainted with the history of world artistic thought, M.F.Akhundzada preferred the second one- closer to the life comparing the East and West literatures from this point of view. It is not accidental that the writings of the outstanding representatives of European literature like W. Shakespeare, J.B.Moliere, F.Fenelon, G.G.Byron, J.Moliere, M.Voltaire, Sh.L.Montesquieu, and J.J.Rousseau always attracted his attentionand he was benefited from the European writers in new type of literary creativity. That's why the enlightenment movement in Azerbaijan, the enlightened realism period in national literature is exactly related to the name of M.F.Akhundzada. 
M.F.Akhundzada entered to the history of national thought as a creator of modernization concept of Azerbaijan society. He kept in mind continiously the matter of modernization of society in his correspondences with his contemporaries- in his rich epistolary heritage, scientific-philosophical writings, thenovella of "The Deceived Stars", the treatise of "Letters of Kemaloud-Dovle" and his plays, this problem constituted the leitmotif of all his creativity. M.F.Akhundzada tried to solve the important problems as launching to publish book, creating national press, achieving freedom of speech and thought, being integrated to Europe in civilization and modernization process. In his mind, it should be performed complex measures for enlightening the nation, creating new type of education system for joining of Azerbaijan to the world and European civilizations above all.

$\mathrm{He}$ realizes that it is enough difficult to implementthese tasks with this illiterate mass, if total illiteracy is related to the conservative, old way of thinking prevails in the society, on the other side, it is related to Arabic alphabet used compulsory by nation as a result of the historical processes arising by invading Azerbaijan by the Arabs.

As a result of scientific analysis and observations M.F.Akhundzada concluded that they should refuse the arabic graphics alphabet leading to the massive illiteracy without delay and complicating much more the writing and readings of Azerbaijanis, as well as unable to fully explain the phonetic nature of the Azerbaijani language, Turkish languages, the basis of articulation, and they have to start to the new alphabet written from the left to the right as Europeans.

For this purpose, he made a new alphabet project and struggled for realizing it until the end of his life. He built close relationships with his contemporaries who are in the same opinion, government representatives, and outstanding intellectuals of his period for realizing his new alphabet project. There is a serious need to the struggle for alphabet and investigating the relationships with his contemporaries scientifically in this field. This is specially importance for preparing an excellent scientific biography of M.F.Akhundzada and from the point of view of valuing writer-thinker's outlook. 
We should note that the problem was investigated in enough tendencies with the direct effect of communism ideology during the Soviet era. (1920-1991). There is a serious need to the comprehensive research of the problem of relationships with his contemporaries in the field of struggle for new alphabet of M.F.Akhundzada in new sociopolitical condition emerging after gaining state independence of Azerbaijan (1991) and turning over the subject of international law.

M.F.Akhundzada had intensive discussions with his countrymen who are outstanding scientific, cultural and religious figures of their time living in Shusha, political, economic and social center of the Caucasus XIX century for realizing new alphabet project. $\mathrm{He}$ corresponded with the persons representing different classes in Iran, and visited to Istanbul (1863) for making discussions with the official and scientific counties considering exceptional importance in development and cultural life building of Muslim nations. M.F.Akhundzada has sent new alphabet project to the important scientific centers of Germany, Austria, France, England and Russia for collecting more supporters for himself among his contemporariesand possibly expanding the geography of dissemination of the idea, getting opinions from them, acquainted his European counterparts with the project. Analyses show that these expectations of M.F.Akhundzadawerejustified itself. Although new alphabet project was greeted with some caution in The Ottoman Empire, and with harsh protest in the level of high political counties in Iran, in any case it was effective and Turkish intellectuals started to widespread discussions in the country and Turkish immigrants in Europe. Besides the supporters of M.F.Akhundzada, there were opponents of his idea. But the main thing is that the issue from the centers to the press then became wide social movement. We should note that when M.F.Akhundzada put forward the issue of alphabet with all his seriousness, he was known as a modern writer in the cultural counties of Russia, The Ottoman Empire, Iran and other European countries.

\section{Literature Review}

In $19^{\text {th }}$ century which entered to history as progress and civilization 
century, M.F.Akhundzada who thinks that the civilization way of nation which he belongs to, passes through the beneficial alphabet and justifies scientific evidences of these thoughts, he strengthenedhis position with relevant examples in the letters addressed to the persons and organizations-in the writings with excellent scientific thoughts and argued with his opponents with his real linguist competence and persuaded them. In the letter addressed to the enlightenment minister of İran M.F.Akhundzada talked about the difficulty of writing and reading with available Arabic alphabet. He often took example of Europe when explaining his thoughts about the problem and explained the development in science and education of Europeans with the excellence of the alphabet. M.F.Akhundzada links Muslim children to being left behind by their European peers in education, not by their personal incompetence, but by the imperfection of the alphabet.[Akhundov, 1955, s.101]. That is why M.F.Akhundzada firmly believed that the alphabet stand on the basis of any progress and tried to persuade his opponents to this. "Building the railroad is important, but it is more important to change the old alphabet. Building telecommunication line is important, but it is more important to change the old alphabet. Because science is a foundation of all work. And science is depending on the easiness of the alphabet. [Akhundov, 1955, p. 109].

\section{Method}

The theoretical basics of the research are the generalization and sistematization. During the analysis and investigation of the texts involved to the study, historical-comparative and analytical-typological methods were used, history and modernity, time and space principles were taken as a basis. The study evaluated the political and ideological tendencies reflected in all the materials reviewed and referenced, approached in the context of that historical period, of the views and opinions of individual authors.

\section{Discussions}

and

\section{Conclusion}

Archival documents and letters to his contemporaries of the writer indicate that M.F. Akhundzada came up 
with the idea of changing the Arabic alphabet in the second half of the 1850s.M.F.Akhundzada archive contains three writings that tell about his study of the history of the Arabian alphabet, the imperfection of the alphabet, and its interpretation of the essence of the new alphabet [Archive of Akhundzada fund 2, storage unit 33, $2+$ 4 pages; storage unit $34,3+3$ pages; storage unit 447, page 24-29]. Each 3 writings were written in 1857.

M.F.Akhundzada understood well that alphabetical reform would be met with protest by forces that have conservative thinking and nihilistic attitude to any innovation. Therefore before taking concrete practical action it was necessary to prove that changing the alphabet wasn't against Islamic religion or the Qur'an.M.F.Akhundzada wrote by referring scientific sources that the Kufi line existed before Islam, and it was written in the alphabet after the Qur'an was revealed. Therefore, just as there is no need for the goddess of the alphabet, there is no harm changing the religion to the religion and Guran. On the other side, at the beginning of the fourth century of the Hijri history, the Arab scholar Ibn alMughla created a naskh line based on the
Kufi line written by the Qur'an.M.F. Akhundzada wrote that if we consider the interests of the people, we can change the nuskh line of Ibn-Mughlana, which is now being used among all the Muslim nations, and if we create more easy method of writing, we wouldn't violate religious and legal norms.. [Akhundov, 1988, III c., p. 56].

Was there an idea of reform or a complete change of the Arabic alphabet before M.F. Akhundzada. In terms of investigating the relationships whether it is scientific or absolutely with his contemporaries of M.F.Akhunzada, the answer to this questionshould be sought.We should note that in Azerbaijan akhund science it has unambigiously affirmed and accepted that the question of inability of the Arabic alphabet for the Turkish people has been raised by Mirza Fatali Akhundzada for the first time in East and Azerbaijan and he has tried to realize his idea until the end of his life. The auther noted the issue of alphabet was raised by M.F.Akhundzada for the first time. He was writing on October of 1857 " there was a need to make an innovation.. in the alphabet of the Islamic writing. Making reform was necessary. But I was in 
charge of renewing work of the alphabet" [Akhundov, 1988, III c., p.19] The importance of accepting the only new alphabet was also putting forward for Europen and Asian countries in the beginning of XIX century. The author of this idea was French enlightener, philosopher, politician Konstantin François Volney(1757-1820). C.Volney suggested this idea in writing of "European alphabet applied to the languages of Asia" which is published inParis in 1819.However, unlike M.F. Akhundzada, K. Volney's goal was not to directly prove the inability of the Arabic alphabet to the Eastern languages. As an author of the idea of reunion of nations in "The head states of Europe", C.Volney suggested the transition to the unit Latin alphabet. The analysis show that the new idea of M.F.Akhundzada differs from the analogical works of French reformer in terms of purposes and essence. C.Volney's alphabet idea was largely emerged on his political views and outlook, but the alphabet idea of M.F.Akhundzada which he tried to realize, was emerged as a demand of the time, the necessity of national-cultural thought and later turn to the wide social- scientific movement, has become a social order, as a result it was realized. This idea in C.Volney couldn't go beyond utopia. According to the rich heritage of M.F. Akhundzada, it could be said that he was acquainted with the outlook and creativity of C.F.Volney. İn his famous writing of "Criticism", he used the name ofC.Volney along with the outstanding thinkers such as Voltaire, Montesquieu, Rousseau, Duma, Humboldt, Box, Shakespeare and Byron.[Akhundov, 1987, p. 332]. He concluded that prominent literature critic Aziz Mirahmadov in his article of "M.F.Akhundov and C.Volney" [Mirahmadov, 1985, p.17] concluded on the basis of analysis that he involved the attention of M.F.Akhundzada not only with hostile attitude to the religion, Feudal despotism, but with the activity on conducting reforms in the alphabet area.[Mirahmadov, 1985, p.17]

M.F.Akhundzada wrote in a letter dated 5 June 1858 to Hussein Nizamuddovla of Tehran that he was working in the Caucasus provinces to justifying and applying the idea of a new alphabet.[Akhundov, 1988, III c., s. 6869]"Caucasus Provinces" refers to the central Tbilisi of the Caucasus, 
Azerbaijan, Dagestan, and the North Caucasus. İt should be noted that in the 19th centuryfamous scholars and clerics of Azerbaijan, as well as the whole of the Orient, such asMohammadaliHuseynzada,

Fazilİravani, Mehdi İsmayıloghlu, Mahammad AfandiMuftizada, Ahmad Huseynzada, HuseynAfandiQayıbov lived in Tbilisi. M.F.Akhundzada discussed his idea of new alphabet with many of these intellectuals and sought ways to realize them.

Akhund Ahmed Huseynzada (1812-1887) was one of the persons whom M.F Akhundzada met regularly in Tbilisi and discussed various issues such as science, culture, literature, education and so on. Epistolary heritage of M.F.Akhundzada proves that Akhund Ahmad Huseynzada always supported him in the issue of neü alphabet. Ahmad Huseynzada who was sheikh-ul-islam of the Causcaus in 1862-1884 was one of the rare religious figures with the democratic style of thinking and rich knowledge. He participated closely in the opening of Azerbaijan department in Gori Teachers' Seminary together with M.F.Akhundzada. Being an outstanding Islamic scholar of his time, he was well
814

versed in secular sciences and wrote several textbooks. Professor V.Guliyev writes that behind the personal relationships of these prominent personalities, very serious social issues have been put forward and they have exchanged views on the necessary reforms that the Islamic world needs. [Guliyev]Akhund Ahmad Huseynzada didn't support the activity on the reform of new alphabet of M.F.Akhundzada, in general he accepted the necessity of changing the arabic alphabet and was a supporter of all these initiatives in this area and showed scientific attitude to this problem. A letter from M.F.Akhundzada to his friend Mirza Melkum khan on June 2, 1871 reveals that M.F.Akhundzada began to seek judgement on contradicting to the Sharia laws of changing the alphabet in scientificreligious sources for protecting his associates.[Akhundov, 1988. III c, s. 173]Existing documents reveals that Sheikh-ul-Islam Ahmad Huseynzada has always been interested in the activities of M.F Akhundzada's well-known contemporaries. Researcher V.Guliyev wrote that he defended the writing of "The only word" (One word) on the reforms in the area of law and in the 
administration system of his friend sheikh-ul-islam Mirza Yusif khan.[Guliyev]

The most active activity of M.F.Akhundzada in the area of realizing his new alphabet idea may be considered his visit to Istanbul. He understood well that in fact, the issue of new alphabet with all its parameters depends on the attitude of The Ottoman Empirerulers to this matter. So that M.F.Akhundzada has prepared to visit The Ottoman Empire some years ago.

It should be noted that in all works that written in Soviet period (1920-1991),the visit of M.F.Akhundzada and its results was reflected in the curved mirror under the influence of political ideology in most cases, and there were many faults. During the Soviet period, the visit of M.F Akhundzada to the Ottoman Empire was silent over the position of the Azerbaijani statesmen and scientists, who had been living in exile in Turkey, in the struggle for the realization of the idea. Undoubtedly it didn't allow fundamentally investigating the problem of M.F.Akhundzada's relationships with his Turkish contemporaries.
The researchers who are the authors of valuable writings on the Azerbaijani literature, culture and history and living in exile in Turkey talked about the alphabet reform in the frame of the life, creativity, scientificsocial activity of M.F.Akhundzada and his visit to The Ottoman Empire for this purpose. In this regard, the articles of "MirzaFataliAkhundzada" [Jaferoghlu, 1933] and "A Certificate about Mirza FataliAkhundzada" [Jaferoghlu, 1934] of an immigrant scholar, professor Ahmad Jafaroghluhave a great importance. Those sources allow studying deeply the relationships with his contemporaries in the matter of new alphabet, and the results of visit of M.F.Akhundzada to The Ottoman Empire

The visit of M.F.Akhundzada was realized in 1863 after 6 years of sending the alphabet project. As it's seen from the records of the writer, he held meetings with prime minister Fuad pasha, foreign minister Ali pasha, enlightenment minister Adham pasha, as well as head translator of Minister of Foreign Affairs, the founder of Society of Science ofthe Ottoman Empire and the enthusiastic supporter of new alphabet 
Munifafandi

in

Istanbul.

M.F.Akhundzada has met highly at the level of government leader in the Ottoman Empire.

İt is clear from the records of M.F.Akhundzada, the alphabet project was discussed firstly by the task of prime minister Fuad pasha on the $10^{\text {th }}$ of July in 1863. In the first discussion M.F.Akhundzada was participated and give a comprehensive explanation on the project. In the second discussion which happened after one week, M.F.Akhundzada hasn't participated for unknown reasons but was informed by Munifafandi who presided over the discussions.

Munifafandi was one of the open-minded personalities of his time, and worked in the Embassy of the Ottoman Empire in Berlin for a while, and was the education minister of the Ottoman Empire at three times. By the initiative of Munifafandi, the Society of Science of the Ottoman Empire and his "Majmuayi-funun" (the compilation of Subjects) journal of 32 pages were created. Dozens of writings on the different fields of science was published in "Majmuayi-funun" of Munif afandi. The article of Munif afandi which supporting the idea of the Azerbaijani thinker was published in the compilation shortly before the visit of M.F.Akhundzada to İstanbul. [Jaferoghlu, 1934]. Munif afandi was in the translator position at the Ministry of Foreign

AffairsM.F.Akhundzada'svisitto

Istanbul.

As it is seen in the records of M.F.Akhundzada, the members of society was agreed principally with his project from the first discussion. The second meeting which he wasn't participate was final and reflected the scientific approach of Mirza FataliAkhundzada to the alphabet project. The clear documents and materials proves that Society members approached the problem completely objective, none of the members had been given tendency instructions related to any issue by government, the most importantly they approached with special respect to M.F.Akhundzada's personality and alphabet project. As it is seen in the records of M.F.Akhundada the necessity of transition to new alphabet has reflected to its details in the final decision of the Society of Science. Thus the alphabet project of 
M.F.Akhundzada was accepted in terms of facilitating the application process with definite modifications by the Society of Science of the Ottoman Empire.

It should be noted that the members of the Society of Science of the Ottoman Empire, led by MunifAfandi have completely implemented their duties.Although there were disagreements about the certain details, the members of the Society appreciated the project and also presented a report to the Ottoman Sultan on M.F Akhundzada's personality and artistic creativity. We should note that the first information about that document was given by exile immigrant A.Jafaroghlu, and published the full text of the report in his journal of "Azerbaijan country knowledge" .[Jafaroghlu, 1934, p. 4145]. In addition to preparation the alphabet project of M.F.Akhundzada, it was emphasized in the report that he was a modern-minded person with rich worldview, an intelligent knowing some western languages, therefore an author of stories.In fact, this document could be considered the end of M.F Akhundzada's visit to Istanbul.
Dozens of authors, including M.F.Akhundzada himself, have analyzed the visit to Istanbul from different perspectives up to now, and came to various conclusions.

But analysis show that it's impossible to perform the project in state level because of the reasons shown in ahead, the visit of M.F.Akhundzada to Istanbul hasn't been ineffective, the movement on the alphabet was founded in the Turkish society, this is important issue has been studied and analyzed systematically by the intellectuals after the visit of Azerbaijani thinker. In letter to his friend, Mirza Yusif khan of Tabriz, who was in diplomatic activity has written about the new alphabet in the newspaper of "Hurriyat "which they published by immigrants in London and about what they are talking about M.F.Akhundzada. [Akhundov, 1988, III p. 285-286].

Despite the desicion of the Science Society of Ottoman, the adoption and implementation of new alphabet in state level wasn't occurred. In addition, promising high-level circles, the writer's dramatic works have not been published in Istanbul. M.F.Akhundzada explained it by the fact 
that Mirza Hussein Khan, the ambassador of Iran in Istanbul at that time, described him as an enemy of the religion with the Ottoman authorities. Thus M.F.Akhundzada explained the idea on new alphabet of not being realized in Ottoman with the subjective factor. In our mind, starting to the implementation of alphabet project of fully approved is related to the international situation of the country and internal situation in the Ottoman Empire on that time. Immigrant researcher, professor A.Jafaroghlu naturally considered that Ottoman government would not enter to a revolution like changing the alphabet in 1863 [Jafaroghlu, 1933, p. 442].The immigrants started a serious struggle to the Ottoman government in Europe in 1860s. The Ottomon government was severely criticized in Turkish emigration press founded by the Society of New Ottomans.

Freedom ideas were peached in the writings of Ali Suavi, Namik Kamal and others. It also should be noted that both Ali Suavi and Namik Kamal spoke in the press about the alphabet and made their suggestions. M.F.Akhundzada was seriously criticized Ali Suavi's suggestions on the new alphabet in the newspaper of "Correspondent" which he published in London and justified its uselessness in arguments. [Akhundov, 1988, II edition p. 259-270].

Thus, the Turkish government couldn't suddenly set this sensitive issue such as changing the alphabet in extremely complicated internal and external situation. Undoubtedly, because of the government doesn't consider the new alphabet as an issue, they couldn't give an opportunity to his political opponents to shoot with their own weapons by taking such a step.

Talking about the views on the new alphabet of M.F.Akhundzada, it's important to learn the relationships of the prominent contemporaries of the writer, as well as some of the officials of this country and the official position of Iran.

As part of M.F.Akhundzada's struggle for the new alphabet, his public relations with his Iranian contemporaries can be clearly seen in the repeatedly published epistolary heritage, which has been preserved in the archives of the writer. In the letters addressed to the prime minister of Iran, Tehran's emir from other officials, Etizadussaltana of the education minister, Hussein khan 
Nizamuddovla, separate diplomats, consul Ali khan, Mustofiyul-Mamalika, Mirza Alakbar who was working translator in Russian Council in Tabriz, the responsible officer of the Ministry of Foreign Affairs and others, M.F.Akhundzadawrote that the new alphabet would open new page in the history of Islamic nationsand the Muslims would join among the developed countries of the world. Although Akhundzade's correspondence with officials was not intensive, correspondence with some Iranian contemporaries later developed into a firm belief friendship and continued for many years. The research of these relations of M.F.Akhundzada with these İranian contemporaries had necessarily great importance. The research of his relations üith Mirza Melkun khan, Mirza Yusif khan, Jalaladdin Mirza, Mohammad JafarGarajadaghi, Mirza agha Mohammad Mehdi helps to identify the philosophy of the outlook of M.F.Akhundzada, and evaluate direct or indirect impact on the literary process and social literary-cultural life of Eastern nations in the second half of XIX century.
Returning to İstanbul in 1863 , M.F.Akhundzada continued strictly his struggle on new alphabet and tried to persuade official Tehran of the necessity of alphabet reforms for the sake of the progress of İslamic nations and sent his developed project and the alphabet project of his friend Mirza Melkun. The emigrant researcher A.Jafaroghlu was writing that, according to its nature, Tehran has denied Mirza's suggestion.[Jaferoghlu, 1933, p. 442].

M.F.Akhundzada agreed with the relevant state authorities on the appeal to Iran about the alphabet beforehand. It shows that M.F.Akhundzada'sactivity in that area, in fact, has been in control of state authorities. It can be seen from the allowance that given to M.F.Akhundzada by relevant state body. “ Major Akhundov! For submitting to necessary institutions of your projects on changing of an old Islamic alphabetyou're allowed to submit to head consul of Iranian state. [Akhundov, 1955, p. 69]. On September of 1868 M.F.Akhundzada applied with the reference to Ali khan, the head consul of Iran in Tiflis. 5 documents were in the reference- the project he made in 1857 , 
the published opinion on the alphabet project his new project, of Science Society of Ottoman Empire, the opinion on the positive characteristics of the project submitted by Mirza Melkum khan, finally the publish opinion of Mirza Melkun khan on changing Islamic alphabet. Apparently, Iran had the opportunity to choose the most suitable option for its respective circles. But the alphabet projects in Iran hadn't only discussed, but also were clearly rejected. According to the records of M.F.Akhundzada, the position of official Tehran was like this: The most rewarding and favourable work would be that Mirza FataliAkhundzada would express his views on changing the Islamic alphabet to the Ottoman leaders. We- Iran nation don't need to change our alphabet Because we have three kind of scripts: nastalik, Shikasta, naskh are higher than all the scripts in the world. We'll never leave our scripts by no means. "We don't comply and would not comply the new script of M.F.Akhnudzada and Melkum khan" Rejection of new alphabet project in Iran may be related to both the conservative way of thinking and subjective factors and to the intense processes happened in the country on that time. It is also possible to link Mirza Hussein Khan's idea that "Changing the Islamic alphabet would lead to the loss of the Gajarid dynasty of Iran. During M.F. Akhundzada's appeal to Iran regarding the new alphabet project and intensive relations with Iranian contemporaries (1857-1868), very serious political processes took place within this country. Nasreddin Shah, who came to power after his father, Shah (1831-1896; years of power: 1848-1896), tried to soften the tense internal politics, while also adjusting to a foreign policy. Of course, he was also inherited with a very complex internal situation together with the throne-crown.The Babylon movement took over the country.The uprising initiated by Sayid Ali Mohammed Bab began in 1850 in Zanjan, which covered almost all of the population's classes was suppressed during the first years of shah's rule. Despite Sayid Ali Mohammad was killed, the Babylon movement has spread to all Iran, gain massive character, different religious sects close to Babylon, as well as Bahaism began to expand rapidly. It is not possible to consider accidental of appearing the 
writing "The beliefs on Babylon" [Akhundov, 1988, II c. p 232-235] of M.F.Akhundzada at that time. In the letter to his friend Mirza Yusif khan on August of 1969, he wrote that the Babylonians rose up in Tehran and there is no knowledge of the alphabet project. [Akhundov, 1988, III c. p.131]..In such complex situation- intense conflict time in the country it was completely impossible to make a decision on changing the İslamic alphabet of the official counties of İran. We think that the rejection of the alphabet project of M.F.Akhundzada by official Tehran was directly related to the mood of internal auditory and the situation in the country at that time. It is also possible to add the wrong approaches of religious views of some authoritive officials.

The results of our analysis shows that either in Turkey or in Iran, the non-acceptance of the new alphabet project was directly related to the extremely complicated external and internal situation in each countries. Here, undoubtedly, the fact that the political power and way of thinking of officials is not at the level that the old alphabet can reject, should be valued as a serious factor.
The scientists, cultural and religious figures who understands the importance of new alphabet-the contemporaries of M.F.Akhundzada must accept this idea, agree with him, work on the promotion of the project and, so on, in fact, should be accepted of fulfilling properly their historical mission within the terms of that period.

Although the new alphabet idea of M.F.Akhundzada wasn't realized by the subjective and objective reasons, the long-standing struggle of the enlightened writer hasn't been ineffective. The researches show that new alphabet idea has founded the new social movement in Azerbaijan under Russian colonialism, as well as in the Ottoman Empire and Iran in the health of M.F. Akhundzada and in his later years, and gained thousands of supporters in shortly time. The social-political situation happened in 1920 allowed to the realization of new alphabet idea and Latin graphics alphabet was applied in Azerbaijan from January 1, 1929 until January 1, 1940. On January 1, 1940, Cyrillic alphabet was applied in Azerbaijan without considering people's will. After gaining independence in 1991, the reasonable measures were taken in state level in 
direction of restoration of Latin graphics alphabet in new social-political situation that appeared. Since 2001, August 1 is celebrated annually as the Alphabet Day in Azerbaijan.

Our studies have shown that the foundation of enlightenment concept of M.F.Akhundzada forms the idea of new alphabet. The idea of new alphabet of writer-thinker was appeared as the result of the long-term observations and analysis. Based on scientific analysis, M.F.Akhundzada concluded that the massive illiteracy of the nation he belongs to, being out of the civilization process occuring in the world is directly related to the difficulty of Arab alphabet and it should be started to the alphabet reforms without delay. But he understood well that it will be difficult to break the resistance of religious fanatics, to persuade to the necessity of the alphabet reform of the society which unable to give up conservative way of thinking, old traditions. That is why M.F. Akhundzada, as an educator, justly proved that changing the Arabic alphabet did not contradict the Quran and Sharia law written in this alphabet, and conveyed his thoughts and ideas to the prominent scholars, culture and clerics of his time.

Our studies show that MF Akhundzada tried to realize the idea of the new alphabet through the Ottoman and Iranian states, given the fact that his country was under Russian colonization. Our analysis shows that MF Akhundzada tried to realize the idea of the new alphabet through the Ottoman and Iranian states, given the fact that his country was under Russian colonization. Studies show that even though the writer-thinker failed to achieve his goal, he was able to unite many of his contemporaries with a great reputation in the community around the idea of a new alphabet, in his letters to friends, expressing his confidence that future generations would fulfil his dream.

\section{References}

Akhundzada M.F (1955).The works would be in 3 volumes III volumes (selected letters). Baku: Azerbaijan State Publishing House, 319 p.

Institute of Manuscripts named after M.Fuzuli of ANAS Archive of MF Akhundzada, fund 2, storage unit 33,2+ 4 pages; storage unit $34,3+3$ sheets; storage unit 447, sheet 24-29. 
Akhundzada M.F (1988) Works

Volume 3 in Volume III. Baku: Science, $388 \mathrm{p}$

Volney C.F. (1819). The European Alphabet applied to Asian languages. Elementary work, useful for any traveller in Asia. Paris, 1 p. 1., (i) viii-xviii, 537 p., 16 tables (13 fold). 8 volume.

Akhundzada M.F. (1987). Literary and philosophical works. Baku: Writer, 368 p.

Mirakhmedov A. (1985). M.F. Akhundzada and K. Volney / The Azerbaijan-European literary literature. Baku: Elm, art. 14-19.

Guliyev V. (2012). Once again about the burial of Mirza Fatali Akhundzada // Newspaper 525, May 19, \# 91 